\title{
PR effects in mixed and unmixed lists
}

WILLIAM G. BRAUD, STEPHEN W. HOLBORN AND PHILIP TOLIN

UNIVERSITY OF IOWA

Pronounciability rating failed to predict ease of learning in two studies employing doubly homogeneous lists (with respect to $\mathrm{PR}$ and form-class). When both $\mathrm{PR}$ and form-class or form-class alone were mixed within lists, $\mathrm{PR}$ has been shown to predict learning. In the present study, PR alone was mixed and found to predict ease of learning.

Two studies have been reported (Braud, Tolin, \& Holborn, 1966; Lindley, 1963) in which pronunciability rating (PR) failed to predict ease of learning of items equated for association value (AV) and frequency. Both of these studies employed doubly homogeneous lists, i.e., lists homogeneous with respect to both PR (easy or difficult) and form-class (CVCs). PR does predict ease of learning of items equated for frequency when these items are presented in lists mixed with respect to both form-class and PR or in lists mixed with respect to form-class but homogeneous with respect to PR (Underwood \& Schulz, 1960). Does PR predict ease of learning of material equated for frequency only in lists where there is a mixed factor-i.e., is this, at least to some extent, a list-specific effect? Would PR predict learning in lists homogeneous with respect to form-class but mixed with respect to PR? The present experiment was conducted in an attempt to answer these questions.

Method

Design and materials. Variation in PR occurred among response items within lists. Each $\mathrm{S}$ learned a 12-pair paired-associate list in which six response terms were easy to pronounce (mean $\mathrm{PR}=3.36$ ) and six difficult to pronounce (mean $P R=5.35$ ). The response items were all low AV, low frequency CVC trigrams identical to those used by Braud et al (1966) and Lindley (1963); exact values of these items appear in the latter report. Stimulus items were the numbers 1 through 12 . Formal intralist similarity was roughly equal in all lists. Four different lists were used to ensure that any relationships found were not due to the peculiarities of a single list. There were three different orders of presentation within each list to prevent serial learning of the response terms.

Procedure. The lists were presented on a memory drum at a 2:2-sec. rate with a 4 sec. intertrial interval. The items were learned to a criterion of one perfect recitation (spelled anticipations) or for 25 trials, whichever took longer. Thus, data for the number of trials to reach the criterion and for the number of correct responses during 25 trials were available.

Subjects. The Ss were 10 male and 10 female
Introductory Psychology students at the University of lowa who had not served previously in similar experiments.

\section{Results}

Table 1 presents the means and SDs for the number of trials to reach criterion and for the number of correct responses over 25 trials for the easy and difficult to pronounce items. Easy to pronounce items were learned in fewer trials than difficult to pronounce items; more easy than difficult to pronounce items were given correctly over 25 trials. The easy and difficult to pronounce items differed reliably on the trials to criterion measure $(t=2.54, d f=19, p<.05)$, but not on number of correct responses over 25 trials $(t=1.01$, df $-19, p>.05$ ). As a further test of the ability of PR to predict ease of learning, a rank-order correlation coefficient was computed between the Underwood \& Schulz (1960) PR value of a trigram and the number of the trial on which that item first occurred as a response, whether correctly or not. This correlation was calculated for the entire range of PR employed, over all four lists. The magnitude of the correlation (Spearman rho $=0.47, \mathrm{p}<.01$ ) indicated that $\mathrm{PR}$ was a good predictor of the length of the integrative or response-learning phase (see Postman, 1961). A rankorder correlation coefficient was also calculated between the Underwood \& Schulz PR value of a trigram and the total number of times that trigram was given as a correct response over 25 trials. The value of this coefficient was $0.30-\mathrm{a}$ value of 0.31 being required to reach the .05 significance level.

\section{Discussion}

While not an important variable in two previous studies (Braud et al, 1966; Lindley, 1963), PR was a predictor of ease of learning of items equated for $\mathrm{AV}$ and frequency in the present study with respect to the trials to criterion measure. Although not significant, the results for number of correct responses were clearly in the same direction. Braud et al (1966) enumerated three possible reasons for the failure of PR to predict learning in their study: (1) It may be that PR is not a useful predictor in doubly homogeneous lists; (2) PR may not predict learning because

Table 1. Means and Standard Deviations of Trials to Criterion and Number of Correct Responses During 25 Trials

\begin{tabular}{lcccc} 
Items & \multicolumn{2}{c}{ Trials to Criterion } & \multicolumn{2}{c}{ Total Correct } \\
& Mean & SD & Mean & SD \\
\hline Easy & 21.10 & 5.98 & 80.00 & 23.15 \\
Difficult & 23.75 & 7.62 & 74.75 & 19.95 \\
\hline
\end{tabular}


of the relatively narrow range of PR sampled; (3) In selecting items equal on two attributes (AV and frequency) but differing on a third (PR), someitems might be picked whose peculiar attributes make their scaling unreliable. The finding of a PR effect in the present study with identical items, while not discounting possible influences of the latter two factors, suggests that list construction is an important variable affecting $P R$ results.

\section{References}

Braud, W. G., Tolin. P.. \& Holbom, S. W. Pronounciability rating and learning of doubly homogeneous paired-associate lists. Psychon. Sci., 1966, 6, 457-458.

Lindley. R. H. Association value, familiarity, and pronounciability ratings as predictors of serial verbal learning. J. exp. Psychol., 1963, 65, 347-351.

Postman, L. Extra-experimental interference and the retention of words. J. e.rp. Psychol., 1961, 61, 97-110.

Underwood, B. J., \& Schulz, R. W. Meaningiulness and verbal learning. Chicago: Lippincott, 1960.

\section{Comment on developmental level and concept learning: A possible artifact by H. E. Klugh}

Te Vault et al (1966) question the interaction of age and intellectual ability reported by Klugh et al (1964, 1965), Friedman (1965), and Pishkin \& Rosenbluh (1966).

Their data are based on a study in which 40 children in each of two age groups are randomly assigned to five experimenters and two types of problem conditions. This yielded a 2 by 2 by 5 design with four Ss in each cell. Te Vault et al report, "The conditions $(F=12.50$, $\mathrm{df}=1 / 780)$ and Experimenters $(\mathrm{F}=9.24, \mathrm{df}=4 / 780)$ main effects, and the Experimenters by Conditions and Experimenters by Conditions by Age interaction ( $F=$ 3.39 , $d f=4 / 780$ and $F=3.75, d f=4 / 780$ ) were all significant at the .01 level of confidence."

The investigators determined that the significant conditions effect and the significant interactions were due to one "deviant experimenter." When this investigator's data were dropped and the result reanalyzed, the only significant remaining effect was among experimenters. Te vault et al concluded, among other things, that "... significant effects of the type reported by Klugh et al, Friedman, and by Pishkin and Rosenbluh can be produced merely by experimenter differences."

Te Vault's conclusions may be true, but they do not necessarily follow from his analysis because he seems to have used an inappropriate error term for testing the significance of the main effects and their interactions. Te Vault gave each of the Ss 10 trials (personal communication) yielding a total of 799 df for the study. His error term, based on $780 \mathrm{df}$, is apparently the result of pooling the sums of squares between Ss in the same cell $(\mathrm{df}=60)$, which is the appropriate error term, with the sums of squares between trials $(\mathrm{df}=9)$ and the total Ss by Trials interaction $(\mathrm{df}=711)$. Since the effects reported are based entirely on variation between $\mathrm{Ss}$, the appropriate error sum of squares should be that between $\mathrm{Ss}$ in the same cell, and thus has just $3 \mathrm{df}$ for each of the 20 cells, yielding a total of $60 \mathrm{df}$.

It then seems possible that the experimental artifact against which $\mathrm{Te}$ Vault cautions is, in this instance, the result of an incorrectly applied analysis of variance.

\section{References}

Friedman, S. R. Developmental level and concept learning: Confirmation of an inverse relationship. Psychon. Sci., 1965, 2, 3-4.

Klugh, H. E., Colgan, K., \& Ryba, J. A. Developmental level and speed of relational concept formation: A possible inverse relationship. Psychon. Sci., 1964, 1, 89-90.

Klugh, H. E., \& Roehl, K. Developmental level and concept learning: Interaction of age and complexity. Psychon. Sci., 1965, 2, 385-386.

Pishkin, V., \& Rosenbluh, E. S. Concept identification of auditory dimensions as a function of age and sex. Psychon. Sci., 1966, $4,165-166$.

Te Vault, R. Kent, Bailey, Melinda, Cagan, Elizabeth, Diones, Joan, \& Figelman, Edith. Developmental level and concept learning: A Possibie Artifact. Psychon. Sci., 1966, 5, 167-168.

\section{Developmental level and concept learning: Reply by $R$. Kent Te Vault}

As Professor Klugh has pointed out in his comment, the analysis of variance reported earlier by us (1966) was in error. The unfortunate use of the incorrect error term occurred in the course of rewriting and shortening a longer paper. The statistical error is a real one and ought to be recognized. At the same time it should be pointed out that the statistical error does not in any way alter the conclusions drawn.

\section{Reference}

Te Vault, R. Kent, Bailey, Melinda, Cagan, Elizabeth, Diones, Joan, \& Figelman, Edith. Developmental level and concept learning: A possible artifact. Psychon. Sci., 1966, 5, 167-168. 